\title{
On the Theme of Nostalgia in Paolo Bacigalupi's Post-Apocalyptic Novel The Windup Girl
}

\author{
Paolo Bacigalupi’nin Post-Apokaliptik Romanı Kurma Kı'da Nostalji \\ Teması Üzerine \\ Murat KABAK*
}

\begin{abstract}
After the massive outbreaks of violence and catastrophes at the dawn of the twentieth century, experiences of dislocation and dissonance, as well as their reflection in the human psyche, nostalgia, captivated the interest of various disciplines from literary studies to politics. Although viewed through various lenses, nostalgia as a state of a wistful affection for the past still permeates the present discourses. These studies on nostalgia overlap with a rising trend in the Western literary canon, the surge of derivative forms of utopia. Building on the contemporary interdisciplinary approaches on nostalgia and dystopian tradition, this paper investigates the individual's position in a dystopian setting with an emphasis on the experience of nostalgia in Paolo Bacigalupi's novel The Windup Girl (2009). This article aims to investigate the role of nostalgia in a post-apocalyptic dystopian setting with a focus on various experiences of nostalgia. I argue that Bacigalupi's novel is a nuanced exploration of the experience of nostalgia and a meditation on the connection between nostalgia and utopianism, due to its engagement with both individual and collective experiences of nostalgia.
\end{abstract}

Keywords: Dystopian tradition, nostalgia, Paolo Bacigalupi, The Windup Girl

$\ddot{O} z$

Yirminci yüzyılın şafağında meydana gelen şiddet ve devasa yıkımların ardından insanların aidiyet ve ahenk hissiyatındaki çöküşün insan ruhuna işlediği nostalji duygusu, edebiyat çalışmalarından siyasete kadar çeşitli disiplinlerin ilgisini çekmiştir. Birçok farklı açıdan bakılmış olsa da nostalji, günümüz söylemlerinde hâlâ geçmişe yönelik hüzünlü bir özlem durumu olarak geçmektedir. Nostalji üzerine yapılan bu çalışmalar, Batı edebiyatı külliyatında gitgide genişleyen bir akım hâline gelmiş ve ütopya türevlerinden oluşan bir dalga yaratmıştır. Nostalji ve distopyacı gelenekteki disiplinlerarası çağdaş yaklaşımları temel alan bu makalenin amacı, Paolo Bacigalupi'nin romanı The Windup Girl'deki (2009) nostalji deneyiminin üzerinde durarak bireyin postapokaliptik distopyacı bir ortamdaki yerini araştırmaktır. Bacigalupi'nin romanının, nostalji deneyiminin ayrıntı11 bir keşfi olduğunu ve nostalji deneyimini hem bireysel hem de kolektif olarak ele almasından dolayı nostalji ve ütopyacılık arasındaki bağlantı üzerine bir tefekkür olduğunu ileri sürmekteyim.

Anahtar Kelimeler: Distopyac1 gelenek, Kurma Kız, nostalji, Paolo Bacigalupi

\section{Introduction}

In her seminal work, The Future of Nostalgia, Svetlana Boym (2001) claims that: "The twentieth century began with a futuristic utopia and ended with nostalgia" (p. xiv). While Boym is referring to the rise and fall of the Soviet regime with its revolutionary vision and the post-Soviet nostalgia, this maxim also reveals the inherent connection between nostalgia and utopia. Both nostalgic mode of feeling and utopian impulse are the products of periods of rapid historical change. The main aim of this article is to investigate the role of nostalgia in a post-apocalyptic dystopian setting with a focus on various experiences of nostalgia in American novelist Paolo Bacigalupi's debut novel The Windup Girl (2009). I argue that Bacigalupi's novel is a nuanced exploration of the experience of nostalgia and a meditation on the connection between nostalgia and utopianism, due to its engagement with both individual and collective experiences of nostalgia. Before moving on to an analysis of the novel, a review of the existing scholarship is in order.

The concerns that were in circulation at the time of The Windup Girl was written, which are confusion, instability, and a sense of discontinuity not only give rise to a nostalgic sentiment but also influence the dystopian fiction. In the context of The Windup Girl (hereaf-

\footnotetext{
* Res. Assist., Istanbul Kültür University, Faculty of Science and Letters, English Language and Literature Department,m.kabak@iku.edu.tr.
}

Kabak, M. (2019). On the Theme of Nostalgia in Paolo Bacigalupi's Post-Apocalyptic Novel The Windup Girl, Gaziantep University Journal of Social Sciences, 18 IDEA Special Issue, 81-91, Submission Date: 30-07-2019, Acceptance Date: 30-12-2019.

Araştırma Makalesi. 
ter $W G$ ), the political and ecological anxieties of the twenty-first century inform the dystopian visions of the novel. As Donnelly (2014) observes, some of the concerns of the early twentyfirst century speculative fiction include the awareness of peak oil, genetically modified food production, the rampant neoliberalism, global terrorism, the awareness of global climate change (pp. 157-158). In line with this view, the existing scholarship, that is already limited in number, only addresses the novel's connection to the ecological and political problems of the twenty-first century. As a generic analysis of the novel, Donnelly's article situates McCarthy's The Road with Bacigalupi's The Windup Girl as the examples of a new of speculative fiction, critical dystopias. While Donnelly (2014) criticizes both novels for their inability of imagining a future beyond capitalism, he also emphasizes their utopian potential as critical dystopias (p. 164). The subgenre, first coined by Lyman Tower Sargent, and later developed by Baccolini and Moylan, designates the novels which emerged during the 1990s and foregrounded open-ended narrative possibilities and maintained the utopian impulse as a reaction to the canonical dystopian form (as cited in Donnelly, 2014, p. 158). King (2016), on the other hand, argues that Bacigalupi uses "the dystopian form to imagine the possibilities for an alternative, post-capitalist future for biogenetics" (p. 5). Lastly, Hageman's article focuses on how Bacigalupi interrogates the dynamics between global capitalism and ecological sustainability. Hageman (2012) reads the environmental catastrophe at the end of the novel as a hopeful future "formed collectively ... by diverse subjectivities intimately and inextricably in contact with each other" (p. 300). While the studies written on the novel address various aspects of the novel from ecocritical, political, and ethical perspectives, their conclusions converge on the same point. That is how to analyze the reconciliation of the ecological and political anxieties at the end of the novel concerning the novel's imagination of an alternative future for humanity? In this article, I aim to answer the same question from a different perspective by focusing on the individual experience of nostalgia. This article aims to analyze how the novel problematizes the nostalgic attitude of various characters.

Set in the twenty-third century Thailand, Bacigalupi's novel follows the events in the aftermath of a catastrophe called "the Contraction" (2012, p. 62). Mega agricultural corporations dominate the food market through genetically modified organisms while the world is devastated by various manufactured plagues. The fossil fuel has depleted, and with global climate change, sea levels have risen. The novel's setting, Bangkok, "the City of Divine Beings" (Bacigalupi, 2012, p. 7), is the only city left unharmed by the devastation out of its "seawalls" and its isolationist regime. The antagonism between two ministries triggers the major narrative events, the Trade Ministry, which advocates the free market, and the Environment Ministry, which seeks to preserve the isolationist position of the Thai Kingdom. This antagonism serves as a narrative frame which converges the fates of a diverse cast of characters, which include an American agricultural company agent, Anderson Lake; a former businessman Hock Seng; a scientist who is helping the Thai Kingdom to develop their genetic stockpile, Gibbons; and the titular windup girl, Emiko. Through focalization, the readers observe the unfolding events from various points of view. Narrated through the perspectives of each character, $W G$ is a showcase of contrasting nostalgic attitudes.

We observe three veins of nostalgia in the novel that are closely connected. Although there is no such distinction of characters in the novel, for our purposes, we may categorize the characters into three groups according to their nostalgic attitudes. The objects of their nostalgia vary in each group as their individual or collective nostalgic attitudes differ. The first group is composed of the Chinese businessman Hock Seng and the American industrial agent, Anderson Lake. Hock Seng's family is slaughtered by an Islamic faction called "the Green Headbands" (Bacigalupi, 2012, p. 21) in Malaya, and he is forced to take refuge in the Thai Kingdom. Hock Seng tries to recover his status as a wealthy man by stealing the factory blue- 
prints and selling them to one of the competitors of Anderson Lake. He is despised as a "yellow card refugee" (Bacigalupi, 2012, p. 4) in Thailand, and he is traumatized by the memories of the massacre in Malaya: "Memories scratch and peck at him, swirling like black crows, hungry to take over his head. So many friends dead. So much family gone. Four years ago, he was a big name. Now? Nothing" (Bacigalupi, 2012, p. 31). As Hock Seng believes that "a smiling girl one day is a girl with a stone bashing in the brains of a baby the next" (Bacigalupi, 2012, p. 72), the extent of his paranoia leads him to pull a knife to a thirteen-year-old Thai girl, Mai (Bacigalupi, 2012, p. 162) who will be mentioned later in the article. His character is derived from one of Bacigalupi's early short stories, "Yellow Card Man" (2010) which is centered around a Chinese refugee who escaped from "the men with their green headbands and their slogans and wet wet blades" (p. 163). While devising a plan to steal the factory plans, Hock Seng recalls his life before the massacre which took his family:

He misses his clipper fleet and the crews (And isn't it true that he hired even the brown people for his crews? Even had them as captains?) who sailed his Mishimoto clippers to the far side of the world ... carrying tea strains resistant to genehack weevil and returning with expensive cognacs that had not been seen since the days of the Expansion. And in the evenings, he returned to his wives and ate well and worried only that a son was not diligent or that a daughter would find a good husband. (Bacigalupi, 2012, p. 69)

This is a very traditional and romanticized way of perceiving the past when "brown people" were 'treated kindly', and the role of the patriarch is to return his home and to enjoy the privileges of being the master of the household. This romanticized past where the social roles and positions are clearly defined draws a stark black and white contrast with Hock Seng's current reality as a despised refugee. Hock Seng's privileged status; however, is not limited to the social aspect, there is also the indication that the Hock Seng of this 'glorious past' had access to expensive and global commodities such as cognac which belonged to the pre-plague world of "Expansion". The mention of "expensive cognacs" and virus resistant tea strains in the middle of his recollection of his family should not escape our attention. It points out that prior to the Green Headband massacre in Malaya, Hock Seng was complicit to the crimes of the agricultural companies that both manufactured the plagues such as "genehack weevil" and produced the virus resistant products to dominate the global food market. Hock Seng, unable to reflect critically on his past and acknowledging his role in the catastrophes, is enchanted by these recollections. This type of nostalgia, for Davis (1979), is "simple nostalgia" which is "the unexamined belief that things were better (more beautiful) (healthier) (happier) (more civilized) (more exciting) then than now" (p. 18). This brief passage illustrates perfectly how Hock Seng's vision of the past and the material reality of his involvement in the approaching catastrophes are distorted by this type of nostalgia.

Resembling Hock Seng's yearning for a past that can never be regained, Anderson Lake's nostalgic attitude appears as an obsession with the golden age. As the advancements in genetically modified species lead to the destruction of the natural ecosystem in the novel, one of the major characters, Anderson Lake, is obsessed with obtaining the seedbank that the Thai Kingdom holds. While looking for clues for a genetic engineer named Gibbons' whereabouts, Anderson Lake looks at the old photographs from the Expansion period:

$[\mathrm{N}]$ one of these pomelos, none of the yellow things ... lemons. None of them. So many of these are simply gone.

But the people in the photo don't know it. These dead men and women have no idea that they stand in front of the treasure of the ages, that they inhabit the Eden of the Grahamite Bible where pure souls go to live at the right hand of God. Where all the flavors of the world reside under the careful attentions of Noah and Saint Francis. (Bacigalupi, 2012, p. 64) 
Lake's obsession with seizing the stockpile of genetic information is given a practical reason in the novel. Using his "kink-spring factory" as a cover for his corporate espionage for the agricultural company AgriGen, Lake tries to seize the genetically unharmed seeds of the Thai government, as well as to find a former AgriGen scientist who is hiding in the Thai Kingdom, Gibbons. Yet, this scene reveals that his obsession with attaining what has been lost is given a religious context. He equates these lost objects of desire with the garden of Eden. Thus, it is no coincidence that "the flavors of the world" are protected by Saint Francis, the patron saint of the environment, and Noah who preserved each animal species from the Great Flood in the Hebrew Bible. The preservation of the species in the Judeo-Christian belief corresponds to the Thai Kingdom's 'seedbank' which Anderson Lake is trying to seize. This photograph is a source of nostalgia for Lake because of its religious connotations. His attempts at obtaining the stockpile is a desire that is projected towards the future, as well as projected in the past. In other words, gaining the knowledge to reproduce the lost seeds would mean to create the prelapsarian unity for Anderson Lake, because his view is heavily informed by the religious group in the novel, the Grahamites. As Selisker (2015) points out, their understanding of nature is also nostalgic:

With frequent reference to Eden and the Biblical flood, the Grahamites' desire to reclaim the natural becomes tantamount to a desire for time travel or global annihilation, since these are the only solutions for returning the world to a state of natural purity. (p. 504)

At this point, we should distinguish the attitudes adopted by Hock Seng and Anderson Lake from a simple nostalgic sentiment since both have unattainable, almost utopic desires. They do not merely cherish the good memories of the past, but they aim to reclaim what has been lost. Hock Seng's yearning is for a "resurrection for himself and his clan" (Bacigalupi, 2012, p. 32), while Lake is in search of "the Eden of the Grahamite Bible" (Bacigalupi, 2012, p. 64). In that respect, both Hock Seng and Lake's longings correspond to what Boym calls restorative nostalgia. From the personal experiences of Hock Seng and the obsession of Anderson Lake, we shall move on to the politics of nostalgia by focusing on the case of the White Shirts.

Boym's concept of restorative nostalgia as "a transhistorical reconstruction of the lost home" (2001, p. xviii) also fits the second group of characters from a collective perspective: The White Shirt captain Jaidee and his protégée Kanya. As Boym (2001) illustrates, the restorative type of nostalgia is complicit to the nationalist discourses because it feeds the conspiratorial view of such discourses:

The conspiratorial worldview is based on a single transhistorical plot, a Manichaean battle of good and evil and the inevitable scapegoating of the mythical enemy. Ambivalence, the complexity of history and the specificity of modern circumstances is thus erased ... "Home," imagine extremist conspiracy adherents, is forever under siege, requiring defense against the plotting enemy. (p. 43)

As we can observe from both the historical and the modern populist right-wing movements, such nationalist discourses are motivated by the restorative type of nostalgia which aims to restore the lost home. However, the return to this imagined home, or the origin, is always threatened by an external force, which is transubstantiated into a metaphysical evil, as Boym suggested. This type of nationalistic discourse in relation to restorative nostalgia is evident at the walls of the temple Wat Phra Seub:

The screens on the temple walls portray scenes of the fall of Old Thailand: The farang releasing their plagues on earth, animals and plants collapsing as their food webs unravelled; his Royal Majesty King Rama XII mustering his final pitiful human forces, flanked by Hanuman and his monkey warriors. Images of Krut and Kirimukha and an army of half-human kala fighting back the rising seas and plagues. (Bacigalupi, 2012, pp. 142-143) 
As the third person narrator describes these apocalyptic scenes, the war between the agricultural monopolies called farang (a European or a foreign in Thai), and the Old Thailand are given mythic qualities. While the outside forces threaten the territorial integrity of the Thais with manufactured plagues, the royal forces are accompanied by the divine power, such as Hanuman who is the destroyer of evil in Buddhism, to defend the motherland. The stakes are not limited to Thailand's security; however, its ecosystem is also in danger. The mythic enemy, farang, is also capable of poisoning the entire ecosystem. In this narrative, "the complexity of history", as Boym points out, is erased. The element that has not been raised in this apocalyptic scene's description is Thailand's regression from a capitalist state to an absolute monarchy. Even though the scenes portray "the fall of the Old Thailand", they are also a part of the official narrative of the Thai Kingdom, describing the transition from the old Thailand to a kingdom.

Now that the relationship between the restorative type of nostalgia and the Thai Kingdom's official ideology has been discussed, we shall return to the second group of characters in the novel and their nostalgic attitude. In the novel, the White Shirts is a group of special forces, commissioned by the Environment Ministry, whose aim is to preserve the genetic purity of the Thai Kingdom. While Jaidee is a captain and an adamant follower of the Environment Ministry, Kanya acts as a Trade Ministry agent. After Jaidee is executed by the Trade Ministry early in the novel, Kanya takes the mantle to lead the White Shirts, but she is haunted by the ghost of Jaidee: "[Kanya] catches the sight of Jaidee, standing at the edge of the ocean, watching the surf ... Another spirit with no place to go" (Bacigalupi, 2012, p. 250). As Anderson Lake's nostalgic attitude is informed by the Judeo-Christian belief system, Kanya's attitude is shaped by Buddhism. She is haunted by the ghost of her former senior officer because she believes that Jaidee is unable to find peace. When her reluctant leadership after the loss of her mentor is combined with a guilty conscience over her betrayal to the Environment Ministry, Kanya begins questioning her role in the conflict. While she is assessing the situation which she is in, Kanya questions whether the crisis is a result of internal conflict within the Kingdom or an external force:

She wonders if it was really better in the past, if there really was a golden age fueled by petroleum and technology. A time when every solution to a problem didn't engender another. She wants to curse those farang who came before (Bacigalupi, 2012, p. 211).

This brief passage should not be taken as a self-questioning on behalf of Kanya since it reflects the racist nationalist attitude fed from the restorative type of nostalgia. The golden age, conceived by Kanya, has two components, technology and fossil fuel, which both are the causes of the environmental catastrophes in the novel. Furthermore, this romanticized past is, like a machine, fueled by these sources. What disturbs this equilibrium, for Kanya, is the external threat.

The paranoid conspiracy theories of the White Shirts can be extended to yet another level. Hock Seng, who is running away from a fundamentalist group in Malaya, is caught up in another conflict between the capitalist expansionist powers of the agricultural monopolies and the nationalist faction in the Kingdom. The massacre perpetrated by the Islamist religious group called the Green Headbands is a commentary on the nationalist zeal of the White Shirts run by Kanya, as Hock Seng is the witness of the atrocities committed by both groups. The Islamist faction, which forced Hock Seng to take refuge in the Thai Kingdom, is also in pursuit of ethnic cleansing. Malaya, the Malaysia of the fictional universe of $W G$ is a multi-ethnic and multi-religious country, while certain ethnic groups such as the Malayan Chinese were targeted by the massacre called "the Incident" (Bacigalupi, 2012, p. 13). The same approach is adopted by the White Shirts, whose abuses are evident in passages where Hock Seng wit- 
nesses the coup attempt by the White Shirts: "The Environment Ministry sees yellow cards the same way it sees the other invasive species and plagues it manages. Given a choice, the white shirts would slaughter every yellow card Chinese" (Bacigalupi, 2012, p. 282). Also, in one of the previous chapters, Kanya contemplates on 'the Malayan problem':

If the Environment Ministry had anything to say about it, all these yellow card refugees would be on the other side of the border. A Malayan problem. The problem of another sovereign country ... But Her Royal Majesty the Child Queen is merciful, compassionate in a way Kanya is not. (Bacigalupi, 2012, p. 208)

While the former faction's atrocities are not given a background other than religious reasons, the latter is motivated by a nostalgic view of Old Thailand, which was free from the reins of economic dependency. Yet, the xenophobia permeating the official discourse of the White Shirts can be extended from illegal immigrant workers to illegal nonhuman immigrants. This is the point where the ultimate nostalgia is observed in the novel.

Emiko, the eponymous windup girl, is one of the members of these humanoid robots created by the Japanese company, Mishimoto. These humanoid beings are despised both by the Thais and the Grahamites "as a joke [or] an alien toy" (Bacigalupi, 2012, p. 36). A similarly hostile manner to the windups is also present in one of the early stories of Bacigalupi, "Yellow Card Man" (2010): "Mishimoto is full of windup import workers, they say. Full of illegal generipped bodies that walk and talk and totter about in their herky-jerky way - and take rice from real men's bowls" (Bacigalupi, 2010, p. 172). As the manual workers speculate on the "generipped bodies" that act like a human, their concern reflects the most basic fear of getting replaced by machines, which is a central theme to many of the turn of the century science-fiction. In this case; however, the replacement is even more terrifying to the laborers because the humanoid machines are replacing the human laborer. Thus, it should not come as a surprise that the White Shirts are also fiercely hostile to the windups. Yet, Kanya's reaction to one of the windups reveals a crucial element. When Kanya interrogates the manager of Mishimoto Company through the middle of the novel, she is, for the first time, confronted by the gaze of a windup. As Yashimoto, the manager of the company, speaks Japanese, his servant Hiroko translates his owner's words. While they discuss the reason why the Japanese created such obedient robots whom they call "the new people", it is not the content of the dialogue that is disturbing for Kanya, but the terrifying presence of a humanoid being: "Kanya keeps her impression impassive. It is difficult. The creature beside her is beautiful. Her skin is sleek, her movements surprisingly elegant. And she makes Kanya's skin crawl" (Bacigalupi, 2012 , p. 297). As there is "no trace of emotion on [Hiroko's] face as she speaks with her owner's voice" (Bacigalupi, 2012, p. 298), the windup girl is without a voice of her own in this scene. She is a pair of eyes confronting Kanya. This confrontation comes right after Kanya speaks with Gibbons on the dichotomy of natural and unnatural, which will be mentioned shortly. This interaction cannot be simply read as the fear of the other because of the ambivalent reaction of Kanya. It is a certain kind of fascination combined with anxiety that is making her skin crawl. There is an alternative way of reading not only Kanya's hostility towards the windups but also the anti-posthumanist attitude adopted by other characters as well. The windup robots, or "the new people" in $W G$ can be seen as Bhabha's "mimic men". The mimicry of the colonized subject is always a threat to the colonizer, just as the new people in $W G$ is an attack upon Kanya's notion of identity. As the colonizer "is threatened by the displacing gaze of its disciplinary double" (Bhabha, 1984, p. 127), Kanya is confronted by the menacing gaze of the Other, which makes Kanya to retreat and assume a defensive position. The position of human is under siege of the new people, as the city of divine beings is under siege of agricultural monopolies trying to take over the genetic material of the Kingdom. Hiroko's presence, in other words, undermines the ontological stability of "human" that Kanya holds 
on to. As opposed to the nostalgic reflexes of Hock Seng and Anderson Lake, in Kanya's case, nostalgia is not a cognitive process triggered by certain events or objects of importance. Instead, it is a drive that motivates the nationalistic discourse of the Kingdom, informing seemingly independent agents to act in certain ways. The anxiety that she feels when confronted with the gaze of the windup, which forces her to question the ontological distinction between human and nonhuman, provides yet another aspect to her complex nostalgic attitude.

After discussing the nostalgic reflexes of characters from personal to political, focusing on Emiko's personal experience of nostalgia seems counterintuitive since this approach takes a step back. However, as I will illustrate, the posthumanist alliance formed by Emiko and Gibbons provides a comment on both the wistful yearnings of Hock Seng and Anderson Lake and the regressive reaction of Kanya. Focusing on the political or environmental issues in $W G$, the existing scholarship fails to address the eponymous windup girl, Emiko's central role to the plot. Before analyzing Emiko's nostalgic attitude concerning the nostalgia experienced by other characters, mentioning Emiko's literary and real-life antecedents is in order. The word, robot, first coined by the Czech writer Karel Čapek, means slave in Czech. Indeed, Emiko is in the position of a slave in the novel. She survives a series of immense humiliations as a sex slave at the sex club she is working. As for the real-life influences for Emiko's creation, Riskin's article focuses on the origins of automata, or the self-operating machines, in the Enlightenment with a focus on "Digesting Duck" and "The Flute Player" androids created by the French inventor Jacques de Vaucanson. The flute-playing satyr attracted Diderot's attention, and this satyr was the first example of an "androïde" that is "a human figure performing human functions" (as cited in Riskin, 2003, p. 613). It also should not escape our attention that even the first android in history is defined in relation to the human figure and human action, albeit it has a nonhuman figure, a satyr. As opposed to Vaucanson's automaton, "the new people" are not merely the imitation of appearance or form. They have also biological functions, as Emiko expresses that her body is a "collection of cells and manipulated DNA" (Bacigalupi, 2012, p. 34).

Not only Hiroko's threatening gaze but also Emiko's presence draws attention to the anti-posthumanist perspective adopted by various characters in the novel. As Emiko distorts the boundaries between human and nonhuman, there are multiple references to Emiko as an animal. While some of the references point out her servile state, as in "an animal. Servile as a dog" (Bacigalupi, 2012, p. 176), the others refer to her feral, animalistic state. Her inability to reproduce is repeated throughout the novel that she is "a genetic dead end. Doomed to a single life cycle" (Bacigalupi, 2012, p. 114). Her role and her body are defined by her Japanese creators. As a slave in Thailand, she is stripped of her name, called only as the windup, and is not in control of her body. On the surface, Emiko's nostalgia is for a time and a place where she was treated almost like a human. Each scene of sexual torture is interrupted by the recollections of her past in Japan:

\section{Look! She is almost human!}

Gendo-sama used to say she was more than human. He used to stroke her black hair after they had made love and say that he thought it a pity New People were not more respected ... But that had been in Kyoto, where New People were common, where they served well, and were sometimes well-respected. Not human, certainly, but also not the threat that the people of this savage basic culture make her out to be. (Bacigalupi, 2012, pp. 34-35)

Later on in the same chapter, as the customers at the sex club at her humiliation, she thinks to herself that: "she is nothing but a silly marionette creature now, all stutter-stop motion ... with no trace of the stylized grace that her mistress Mizumi-sensei trained into her" (Bacigalupi, 2012, p. 37). Her condition as a survivor resembles Hock Seng's condition who 
is also treated as a subhuman in the Thai Kingdom. Hock Seng and Emiko are both other to the Thais as well as to the Grahamites, and they yearn for an unattainable past. Yet, their difference lies in what Davis (1979) calls "reflective nostalgia" which is the attempt to reflect upon the significance of nostalgic recollection (p. 25). Her past where she was treated almost as a human is not compatible with her present condition; however, as opposed to Hock Seng, Emiko is able to critically reflect upon the significance of her recollections and the meaning of home: "Somewhere beyond the armies of war for shares of coal and jade and opium, her own tribe awaits her. She was never Japanese; she was only ever a windup. And now her true clan awaits her" (Bacigalupi, 2012, p. 102). Unlike Hock Seng, Emiko does not allow her recollections distorting the reality of her condition in Japan. She yearns for past but at the same time acknowledges her position in the eyes of her Japanese creators. Even though she is respected as a nonhuman being, she is still disposable: "She [Emiko] remembers how Gendosama took her and showered her with affection and then discarded her like a tamarind hull" (Bacigalupi, 2012, p. 252). Emiko does not allow her wistful yearning clouding her judgement. Instead of compensating her longing with her new patron, Anderson Lake, she is in search of a windup enclave populated by the runaway robots without owners, in other words, in search of a home where she can be free.

Closely connected to Emiko's critical evaluation of the relationship between the present and the past, the last character I will focus on is Gibbons. While Anderson Lake's nostalgic regard for nature is related to his belief that the pre-plague world was equal to the Arcadian existence, there is also a contrasting nostalgic attitude in the novel. The last approach is a critical one, especially critical on Lake's view. Gibbons, an aging genetic engineer who is helping the Thai Kingdom to preserve their genetic treasure, now lives the last days of his life surrounded by transsexual robots he created. As I illustrated, while the New People are shunned by the Thais and the Grahamites alike, Gibbons is the only character who shows hospitality to them. For Gibbons, the obsession with retrieving the lost fruits or the fixation with what is natural and unnatural are nothing but regressive reactions to change and progress. During a heated debate with Kanya, Gibbons draws attention to the absurdity of this dichotomy: "'The food web you talk about is nostalgia, nothing more. Nature.' ... 'We are nature. Our every tinkering is nature, our every biological striving. We are what we are, and the world is ours. We are its gods"' (Bacigalupi, 2012, p. 243). Gibbons' views show the interpretative side of nostalgia which Davis (1979) defines. In this respect, his view on the connection between nature and human contrasts Lake's beliefs. At the end of the novel, Gibbons finds Emiko among the ruins of the city and promises her with the ability to procreate. As King (2016) observes, the posthuman alliance between Gibbons and Emiko is "an ideological negation of the White Shirts and Kanya" (p. 12). However, even though Gibbons seems to be engaging in a critique of human being's relationship with nature, his discourse is very much aligned with the anthropocentric ideology that perceives human as "the paragon of animals" when he emphasizes the position of human as the god of nature. Moreover, he continues by promising the garden of Eden to Kanya: "If you would just let me, I could be your god and shape you to the Eden that beckons us" (Bacigalupi, 2012, p. 243). Even though he seems to be more conscious of the shortcomings of the White Shirt ideology or the anti-posthumanist approaches than the other characters, he also cannot overcome the paradoxes of his discourse which relapses into Judeo-Christian register. As the other characters rely on the symbols, objects, or recollections of the past in the hope of a return to a coherent time, they seek refuge in nostalgia. The only difference, in Gibbons' case, is that nostalgia is not directed towards the past but the future. His seemingly posthumanist attitude is poisoned by the messianic tone of his dialogue. 
As Tannock (2006) pointed out the nostalgic processes of sadness of separation have been regarded with skepticism in the literature (pp. 454-455), while utopian writing is deemed as forward-looking. However, I argue that nostalgia and utopian fiction have an intrinsic connection due to their conception of the past, the present, and the future. There is a nostalgic aspect to utopian writing in the form of grief for the loss of Eden after 'the Fall'. On the other hand, there is a utopian vision in the experience of nostalgia in the form of the recreation of the prelapsarian unity on earth. In other words, the yearning for the lost home and the drive to recreate it on earth coincide in the experience of nostalgia in utopian fiction. As we have seen in Anderson Lake's discourse which he adapted from the Grahamites, there is this nostalgic utopian vision of recreating the human condition before the catastrophe. Nostalgia serves a practical purpose that gives certain characters a seemingly solid sense of existential security. It is, for them, a means to hold onto certain nationalist values, memories or objects of importance which connect them to secure ground. Yet, this reactionary state removes them from their current reality. In a sense, their obsession with a past that cannot be reclaimed is their tragic flaw. That leads us to our third point, reconciliation. If, nostalgic attitude is regressive and reactionary, what is the solution that The Windup Girl offer?

Victor Turner (1974/1987) argued that a temporary suspension or destruction of a formal social structure is required for a sense of communitas to be established (p. 251). The Windup Girl, in that respect, creates the prerequisite suspension of the social order by destroying the city at the end. Yet, we shall avoid the pitfall of reading the novel's end as the creation of a utopian community. Anderson Lake, or the foreign devil as Hock Seng calls him, dies because of what he unwittingly helped generate, a disease that spreads from his king-spring factory which he used as a cover for his espionage. In the same vein, Gibbons' utopian project depends on a recreation of the garden of Eden. On the other hand, Hock Seng, who is complicit to the crimes committed by the agricultural companies, has his defining moment when he amends his selfish ways by sacrificing his life to save a Thai girl, named Mai. Even though he experiences nostalgia in the first degree, as Davis calls it, Hock Seng's nostalgic reflection helps him to bestow meaning upon his present condition and considers Mai as his daughter. On the other hand, the ultimate nostalgia, which was hinted in Gibbons' words to Kanya, can be found in the human's adherence to millennia-old ontological categories by clearly defining the boundaries between the human and the nonhuman. Yet, Gibbons' discourse also should not be confused with a posthumanist one. He is very much transhumanist, as the following excerpt from his monologue to Kanya illustrates:

You die now because you cling to the past. We should all be windups by now. It's easier to build a person impervious to blister rust than to protect an earlier version of human creature ... You cling to some idea of a humanity evolved in concert with your environment over millennia, and which, you now, perversely, refuse to remain in lockstep with. (Bacigalupi, 2012, p. 243)

Gibbons never makes it clear whether he wants to improve the human condition or create a new one until the end of the novel. His view of human lingers between the strands of posthumanism and transhumanism. As Wolfe (2010) points out, in contrast to posthumanism as a philosophical moment of the decentering of the human, transhumanism is "an intensification of humanism" (p. xv) as it aims to perfect the human being by eliminating the human limitations. This ideal is motivated by the same thought already present in Kant's "What is Enlightenment?" (1784): "Enlightenment is man's leaving his self-caused immaturity ... The motto of the enlightenment is therefore Sapere aude! [Dare to know!] Have courage to use your own intelligence!" (as cited in Wolfe, 2010, p. xiv). What motivates Gibbons' actions is his god complex. While he employs a transhumanist approach by promising the improvement of human species when addressing Kanya, the same discourse shifts into a posthumanist one at the end when Gibbons plays the role of god for Emiko. As it is evident in the paradoxes of 
his own discourse, even Gibbons, who is the most critical of the conservative attitudes of the other characters, is not a viable model to rebuild the fictional world of $W G$.

In Living in the End Times (2010), Slavoj Žižek that the global capitalism is approaching a catastrophe and "the four riders of the apocalypse" are "the ecological crisis, the consequences of the biogenetic revolution, imbalances within the system itself ... and the explosive growth of social divisions and exclusions" (p. x). The Windup Girl, published only a year before Žižek's book, addresses each rider in detail and it is not unambiguous on its treatment of its main concerns. One of the concerns that informed the novel is automation and technology, or more specifically, technology's use in biogenetic research. While King (2016) argues that $W G$ provides "the possibilities for an alternative post-capitalist future for biogenetics" (p. 5), the reality of the situation in the novel is not as uncomplicated as King conceives. Early in the novel, there are mentions of animals called megodonts which are genetically engineered species of mammoth for heavy manual labor. While Fukuyama argued that with the advancement of capitalism, we reached 'the end of history' where no development is needed, Žižek is critical of this notion. As illustrated above, Bacigalupi's future society is also critical of such utopic vision that global capitalism or advanced research on biogenetics would deal with the problems of our present condition. On the contrary, as seen from the example of megodonts, biogenetic research is used as an instrument by capitalism to reinstate its power in a changing world. While the fictional world of The Windup Girl changes with global catastrophes and climate change, global capitalism also reconfigures itself into adapting into this new environment.

The Windup Girl is currently an understudied work of science-fiction, which is powerful in its implications for a future society which is haunted by the issues that are not altogether different from our present concerns. Sets in the twenty-third century, The Windup Girl's nostalgic past is our present. As Anderson Lake yearns for an idyllic time where "the food web" has not yet been unravelled by the manufactured plagues and global climate change, the dangers are imminent, and we are approaching a catastrophe, as Žižek claims. Bacigalupi's novel neither provides with a blueprint for an ideal post-capitalist society nor all doom and gloom. It is a nuanced work that revolves around our predicament today. The novel's richness and multiple responses to the issues it presents resist neat classifications. Bacigalupi represents these different nostalgic attitudes without privileging one over the others. Hence, the multiplicity of voices creates a composite image of reconciling this dystopian future with an ambiguous one, leaving the reader to contemplate on the uses of nostalgia.

\section{References}

Bacigalupi, P. (2010). Yellow card man. In P. Bacigalupi, Pump six and other stories (pp. 163-195). London: Night Shade Books. (Original work published in 2006)

Bacigalupi, P. (2012). The windup girl. San Francisco: Night Shade Books. (Original work published in 2009)

Bhabha, H. (1984). Of mimicry and man: The ambivalence of colonial discourse. October 28, 125-133. doi:10.2307/778467

Boym, S. (2001). The future of nostalgia. New York: Basic Books.

Davis, F. (1979). Yearning for yesterday: A sociology of nostalgia. New York: Free Press.

Donnelly, S. (2014). Peak oil imagining in Cormac McCarthy's The road and Paolo Bacigalupi's The windup girl. English Academy Review: Southern African Journal of English Studies, 31(2), 156-169. doi:10.1080/10131752.2014.965428 
Hageman, A. (2012). The challenge of imagining ecological futures: Paolo Bacigalupi's The windup girl. Science Fiction Studies, 39(2), 283-303. doi:10.5621/sciefictstud.39.2.0283

King, D. (2016). Biogenetics, the nation, and globalization in Paolo Bacigalupi's critical dystopias. MOSF Journal of Science Fiction, 1(1), 4-16.

Riskin, J. (2003). The defecating duck, or, the ambiguous origins of artificial life. Critical Inquiry, 29(4), 599-633. doi:10.1086/377722

Selisker, S. (2015). "Stutter-stop flash-bulb strange": GMOs and the aesthetics of scale in Paolo Bacigalupi's The windup girl. Science Fiction Studies, 42(3), 500-518. doi:10.5621/sciefictstud.42.3.0500

Tannock, S. (2006). Nostalgia critique. Cultural Studies, 9(3), 453-464. doi: $10.1080 / 09502389500490511$

Turner, V. W. (1987). Passages, margins, and poverty: Religious symbols of communitas. In V. W. Turner, Dramas, Fields, and Metaphors: Symbolic Action in Human Society (pp. 231-271). Ithaca and London: Cornell University Press. (Original work published in 1974)

Wolfe, C. (2010). What is posthumanism? In C. Wolfe (Ed.), What is Posthumanism? (pp. xixxxiv). Minneapolis: University of Minnesota Press.

Žižek, S. (2010). Living in the end times. London: Verso. 